\title{
Red-Leg in Tree-Frogs Caused by Bacterium alkaligenes
}

\author{
BY ELLEN M. MILES \\ National Institute for Medical Research, Mill Hill, London, N.W. 7
}

\begin{abstract}
SUMMARY: The individual animals in a large batch of European tree-frogs imported into England from Italy were found to be suffering from what proved to be, with two exceptions, a uniformly fatal attack of typical red-leg. Bacterium alkaligenes was isolated in profusion in pure culture from the heart blood and lymph fluid of all the frogs examined. The strain was highly susceptible to streptomycin, and the only animals to recover were two that were treated with 1000 units of the antibiotic, in divided doses over 9 days.
\end{abstract}

Red-leg in frogs has in the past always proved to have been due to a bacteraemic infection by Proteus hydrophilus Bergey et al. (see Kulp \& Borden, 1942) or to very similar bacilli. This report concerns red-leg due to an entirely unrelated bacterium.

Red-leg in tree-frogs. In July 1949, during a search for fresh Pr. hydrophilus strains, I examined a batch of over fifty European adult tree-frogs ( Hyla arborea (Linn.)) which had arrived at the London Zoological Society's Gardens from North Italy, packed in a very crowded container. Soon after arrival, many deaths from red-leg occurred, and it was evident that the whole batch was likely to be attacked. Of the surviving frogs, some four-fifths died before examination was possible, but six were observed while dying, and examined immediately.

Their normally bright, moist green skins were dull and brownish. There were red pustules and a red gelatinous material round the mouth and on the fingers and toes. Bright red mottling and small petechial haemorrhages were present on the skin of the thighs and abdomen. The subcutaneous lymph was copious and blood-stained, and the body-cavity filled with blood-stained exudate. The heart was pale, with prominent superficial vessels. The lungs were intensely bloody in three animals, and apparently normal in the rest. The liver was greenish and soft, and the surface of intestines flecked with sub-peritoneal haemorrhages. The kidney and spleen were apparently normal. Gram-negative bacilli were in profusion in the lymph and peritoneal exudate; none were seen in the heart blood. Direct plating of lymph and heart blood in all six cases yielded profuse, pure cultures of a Gram-negative bacillus which proved to be typical strains of Bacterium alkaligenes.

Description of the strain isolated. A Gram-negative non-acid fast rod, $0.5 \times 1-1.5 \mu$., feebly motile by peritrichate flagella. Mainly coccobacillary, occasionally filamentous. On horse blood agar, in one day at $37^{\circ}$, the colonies were $0.5 \mathrm{~mm}$., round, moist, domed, semi-translucent and yellowish; nonhaemolytic. Failed to ferment a wide range of the bacteriological 'sugars'. Citrate, indole, methyl red, Voges-Proskauer, catalase, $\mathrm{NH}_{3}$ and $\mathrm{H}_{2} \mathrm{~S}$ negative. Nitrate not reduced to nitrite. Gelatin not liquefied. Litmus milk feebly alkaline in 2 days at $37^{\circ}$, without ropiness. Grows better at $37^{\circ}$ than at $20^{\circ}$. 
Not agglutinated by antisera to authentic strains of Haemophilus bronchisepticus.

Three normal adult specimens of Rana temporaria were given $0.4 \mathrm{ml}$. of an $18 \mathrm{hr}$. broth culture subcutaneously. All survived for 4 weeks without a sign of disease, and displayed no abnormalities at post-mortem examination. No specimens of the tree-frog were available for pathogenicity tests.

Treatment of the red-leg by streptomycin. Epizootics of red-leg may seriously diminish or wholly destroy colonies of frogs in captivity. Suppression of the epizootic by segregation and chilling of the individual frogs, as recommended by Emerson \& Norris (1905) though successful, is laborious, and may spoil the animals, for example, as objects of physiological research. The organism was susceptible to streptomycin in vitro. Titrated in heart-broth in a two-fold dilution series, streptomycin was bacteriostatic for the Bact. alkaligenes strain in half the minimum concentration needed for bacteriostasis of Waksman's susceptible strain of Bact. coli.

The curative effect of streptomycin was therefore tested. From the remnant of the original batch five tree-frogs were selected and each of them was isolated. Three received subcutaneous injections of $0.2 \mathrm{ml}$. of a $1000 \mathrm{unit} / \mathrm{ml}$. solution of streptomycin in distilled water; the dose was repeated on the 2nd, 3rd, 6th and 9th days, a total of 1000 units being given. One of these animals had advanced red-leg, of a degree which had in other animals indicated death in 1-2 days; it survived for 1 week. Two with incipient red-leg-sluggish, with dull, dark skins and faint pink flush over the thighs and belly wall-were bright and active in $48 \mathrm{hr}$., and recovering their glossy green colour. They recovered completely, and were well 3 months later.

The rest of the batch of tree-frogs in a sense serves as a control in this test, because all without exception died. The two remaining frogs of the five selected had no visible signs of red-leg at the beginning of the streptomycin test. They received only distilled water in $0.2 \mathrm{ml}$. doses; both died of red-leg, one in 2 , the other in 4 days.

\section{COMMENT}

Though its power to reproduce the disease in the susceptible animal could not be proved, there can be little doubt that the Bact. alkaligenes was the cause of the haemorrhagic septicaemia in these tree-frogs. It must therefore be added to Proteus hydrophilus as one of the causes of red-leg in amphibians. Its nonpathogenicity for common frogs (Rana temporaria), which were from a batch known to be susceptible to experimental Proteus hydrophilus infection, suggests that its host range is more restricted than that of Pr. hydrophilus.

The very limited evidence from the therapeutic tests suggests that streptomycin treatment is well worth a trial in red-leg of captive frogs caused by this bacillus.

I am indebted to Dr E. Hindle, the Scientific Director of the Zoological Society of London, for the opportunity to investigate the epizootic of red-leg; and to Mr H. Proom of the Wellcome Research Laboratories for tests with $\boldsymbol{H}$. bronchisepticus antisera. 


\section{REFERENCES}

Emerson, H. \& Norris, C. (1905). 'Red Leg', an infectious disease of frogs. J. exp. Med. 7, 32.

Kulp, W. L. \& Bonden, D. G. (1942). Further studies on Proteus hydrophilus, the ecological agent in 'Red Leg' disease of frogs. J. Bact. 44, 673.

(Received 15 January 1950) 